\title{
Economic Benefit and Greenhouse Gas Emission Reduction Potential of A Family-Scale Cowdung Anaerobic Biogas Digester
}

\author{
Agus Haryanto ${ }^{\mathrm{a}, *}$, Dwi Cahyani ${ }^{\mathrm{b}}$, Sugeng Triyono ${ }^{\mathrm{a}}$, Fauzan Murdapac, Dwi Haryono ${ }^{\mathrm{d}}$ \\ a Department of Agricultural Engineering, Faculty of Agriculture, the University of Lampung, Indonesia. \\ ${ }^{b}$ Department of Agricultural Engineering, Wageningen University, Droevendaalsesteeg 2, 6708 PB Wageningen, The Netherlands. \\ c Department of Civil Engineering, University of Lampung, Bandar Lampung, 35144, Indonesia. \\ ${ }^{d}$ Department of Agribusiness, University of Lampung, Bandar Lampung, 35144, Indonesi,.
}

\begin{abstract}
The objective of this research is to evaluate economic benefit and greenhouse gas (GHG) emission reduction potential of a family-scale anaerobic cowdung biogas digester. Research was conducted at two villages in Lampung Province, namely Marga Lestari, District of South Lampung and Pesawaran Indah, District of Pesawaran. Economic benefit and GHG emission reduction potential were evaluated based on LPG saving due to biogas utilisation for cooking and slurry digestate utilisation for fertilizer substitution. Results showed that a family-scale anaerobic cowdung biogas digester demonstrated a good potential to reduce GHG emission, but not in economic. A digester with 5 heads of cow produced biogas at a rate of $1582 \mathrm{~L} /$ day. With average methane content of 53.6\%, energy value of the biogas was equivalent to $167 \mathrm{~kg} \mathrm{LPG}$ and able to substitute 52 bottles LPG annually. A family-scale biogas digester contributed 111.6 USD/year and potentially reduced GHG emission by $2674.8 \mathrm{~kg}$ $\mathrm{CO}_{2} \mathrm{e} /$ year. Development of family scale biogas-digesters should be integrated with organic fertilizer production and smallholder agriculture.
\end{abstract}

Keywords: biogas; cowdung; greenhouse gas; economy; benefit.

Article History: Received November 15 ${ }^{\text {th }}$ 2016; Received in revised form January 16 th 2017; Accepted February 2nd 2017 ; Available online How to Cite This Article: Haryanto, A., Cahyani, D., Triyono, S., Murdapa, F. and Haryono, D. (2017) Economic Benefit and Greenhouse Gas Emission Reduction Potential of A Family-Scale Cowdung Anaerobic Biogas Digester. Int. Journal of Renewable Energy Development 6(1), 29-36. http://dx.doi.org/10.14710/ijred.6.1.29-36

\section{Introduction}

Lampung has a great potential to develop familyscale biogas digesters due to significant growth on household animal husbandry, especially for cow fattening. The population of beef cattle in Lampung has slightly increased from 573,483 heads in 2013 to 660,745 heads in 2016 (BPS, 2016). Generally, farmers raise 3 to 5 heads of cow as a secondary activity. Household animal husbandry poses a significant role for farmers in villages. The cows can be used for power traction during land preparation (ploughing and harrowing) and transportation of farm products from the fields. In a needy situation, these animals can also be used as a cash animal.

The cow produces a significant amount of manure. According to ASAE Standard D384.1 the quantity of manure excreted by a cow is $5.8 \%$ (wet basis) of its weight (ASAE, 2003). Cow manure is primarily composed of organic materials and water. With no proper treatment, this manure may emit methane $\left(\mathrm{CH}_{4}\right)$, one of important greenhouse gases (GHGs), to the atmosphere (Bird and Sumner, 2011). Under anaerobic conditions, the organic materials will be decomposed by anaerobic and facultative bacteria. The end products of anaerobic decomposition are methane, carbon dioxide, and stabilized organic materials. The emitted methane can be captured by constructing lids or caps for lagoons, tanks, or digesters to keep manure anaerobically. The recovered methane can be used as a fuel for many application such as cooking, lighting, or electricity generating engine.

Traditionally, most farmers in Indonesia handle the manure by simply collecting and stacking it nearby the pen. The manure is then picked up after six months and used as compost by spreading it on the fields. During the stacking period, anaerobic process undergoes inside

* Corresponding author: agus.haryanto@fp.unila.ac.id (Agus Haryanto) 
Citation: Haryanto, A., Cahyani, D., Triyono, S., Murdapa, F. and Haryono, D. (2017). Economic Benefit and Greenhouse Gas Emission Reduction Potential of A Family-Scale Cowdung Anaerobic Biogas Digester. Int. Journal of Renewable Energy Development, 6(1), 29-36, doi.org/10.14710/ijred.6.1.29-36

$\mathrm{P}$ a g e $\mid 30$

the piled manure that emits methane. With a sound management, however, cow manure can be used to produce renewable energy in form of biogas through anaerobic digestion. Cow manure can be explored to produce renewable energy (biogas) and fertilizer (compost) through anaerobic digestion process. The biogas can be used to substitute traditional cooking fuels such as fuelwood and kerosene as happened in India (Kandpal et al., 1991), Nepal, and Bangladesh (Kabir et al., 2012). Whilst, slurry digestate can be utilized as a good compost. In fact, cow manure presents an important potential of renewable sources for energy and fertilizer. Regarding the socio-economic features of villagers in less developing countries, the biogas produced from renewable sources is the right option in meeting both energy and environmental requirements (Kabir et al., 2013).

In Indonesia, household biogas is applied mainly as substitute for LPG (liquefied petroleum gas) following kerosene-to-LPG conversion program initiated by government in 2007. The policy of this conversion program was regulated under President Regulation No. 104/2007 on The Rules, Distribution, and Price Determination for $3 \mathrm{~kg}$ LPG bottle, Regulation of Ministry of Energy and Mineral Resources No. $021 / 2007$ on The Implementation, Supply, and Distribution of $3 \mathrm{~kg}$ LPG bottle, and President Regulation No. 28/2008 on The Price of 3 kg LPG Bottle for Domestic and Micro Scale Business (Lie, 2009).

In some countries such as China (Chen et al., 2014), India (Singh and Sooch, 2004), Nepal (Forte, 2011), Bangladesh (Khan et al., 2014), and Vietnam (An et al., 1997), family sized biogas technologies play a significant role to fulfill energy need, especially in the rural areas. By the end of 2010, China has installed 41.18 million household biogas digesters in rural areas with an annual biogas output of 15.5 billion $\mathrm{m}^{3}$ (Feng et al., 2014). In India, the National Biogas and Manure Management Program implemented by Ministry of New and Renewable Energy has successfully installed more than 4 million biogas plants in the country as of 2010 (Schmidt and Dabur, 2014). Barnhart (2014) reported that Nepal has installed around 250,000 units of biogas digester that saved 239,386 tons of fuelwood per year and 3,830,000 liters of kerosene. The total number of installed biogas digesters in Vietnam accounted for about 200,000 units (Nguyen, 2011). Recently, Bangladesh has installed more than 40,000 domestic biogas plants using cow dung or poultry litter (Khan et al., 2014). Domestic biogas is also growing in Africa thanks to support from Netherlands Development Organization SNV (Stichting Nederlandse Vrijwilligers). In 2009, a total of 53,617 biogas plants were installed in Africa (Ghimire, 2013).

Adoption of household biogas digesters in Indonesia is quite slow compared to those mentioned countries. Since 2009, Indonesia has received support from Netherlands Government to promote domestic biogas through a program called Indonesia Domestic Biogas Program, popularly called BIRU (Biogas Rumah). As of March 2015, the number of digesters has reached 14,478 across nine provinces (Vorley et al., 2015). Slow adoption of biogas technology in Indonesia may be resulted from its unclear benefit.

The objective of this research is to evaluate economic and environmental benefits of family size cowdung biogas digester.

\section{Materials and Methods}

\subsection{Location description}

Research was conducted at two villages in Lampung Province, namely Marga Lestari Village, Subdistrict of Jati Agung, District of South Lampung and Pesawaran Indah Village, Subdistrict of Padang Cermin, District of Pesawaran (Figure 1). In these villages, farmers prefer to raise mostly PO (Peranakan Ongole) cattle. The reason is that $\mathrm{PO}$ cattle has such advantages as high adaptability to tropical climate, resistant to heat, resistant to parasites disorders like mosquito bites, and also good tolerance to feed containing high crude fiber. These cattle also good for dual purpose as beef cattle and working cow as well. Generally farmers allow the cattle for grazing during day time. The both villages were intentionally selected because there were a number of families got involved in the biogas digester installation and operation. The biogas was used solely for cooking in those two areas.

A total of 4 biogas digesters were observed in detail to evaluate their performance (Table 1). All digesters at Marga Lestari were constructed using polyethylene (PE) tubular plastic (Figure 2a) with a diameter of 90 $\mathrm{cm}$ and length of 4 to $5 \mathrm{~m}$ and equipped with separated gas holder to collect and store the biogas. The digesters in Pesawaran Indah were fixed-dome type constructed using cement concrete with a capacity of 4 and $6 \mathrm{~m}^{3}$ without separated gas holder (Figure 2b). In both villages, fresh cowdung was mixed with water at a ratio of water to cowdung $1: 1(\mathrm{v} / \mathrm{v})$ prior to loading in the digester. This is purposed to increase flow-ability and to reduce $\mathrm{TS}$ of the substrate.

Table 1

Description of digesters used in the experiment.

\begin{tabular}{|c|c|c|c|c|c|}
\hline Digester & Location & $\begin{array}{c}\text { Capacity } \\
\left(\mathrm{m}^{3}\right)\end{array}$ & $\begin{array}{l}\text { Number } \\
\text { of cow } \\
\text { (head) }\end{array}$ & $\begin{array}{l}\text { Loading } \\
\text { Freq. }\end{array}$ & $\begin{array}{l}\text { Loading } \\
\text { Amount } \\
\text { (L/day) }\end{array}$ \\
\hline $\begin{array}{l}\text { A (Tubular } \\
\text { plastic) }\end{array}$ & $\begin{array}{l}\text { Pesawaran } \\
\text { Indah }\end{array}$ & 3.5 & 3 & $\begin{array}{l}\text { Twice } \\
\text { a week }\end{array}$ & 80 \\
\hline $\begin{array}{l}\text { B (Tubular } \\
\text { plastic) }\end{array}$ & $\begin{array}{l}\text { Marga } \\
\text { Lestari }\end{array}$ & 4.7 & 4 & Daily & 80 \\
\hline $\begin{array}{l}\mathrm{C} \text { (Fixed } \\
\text { dome) }\end{array}$ & $\begin{array}{l}\text { Pesawaran } \\
\text { Indah }\end{array}$ & 6 & 6 & Daily & 150 \\
\hline $\begin{array}{l}\text { D (Fixed } \\
\text { dome) }\end{array}$ & $\begin{array}{l}\text { Pesawaran } \\
\text { Indah }\end{array}$ & 6 & 5 & $\begin{array}{l}\text { Twice } \\
\text { a week }\end{array}$ & 120 \\
\hline
\end{tabular}




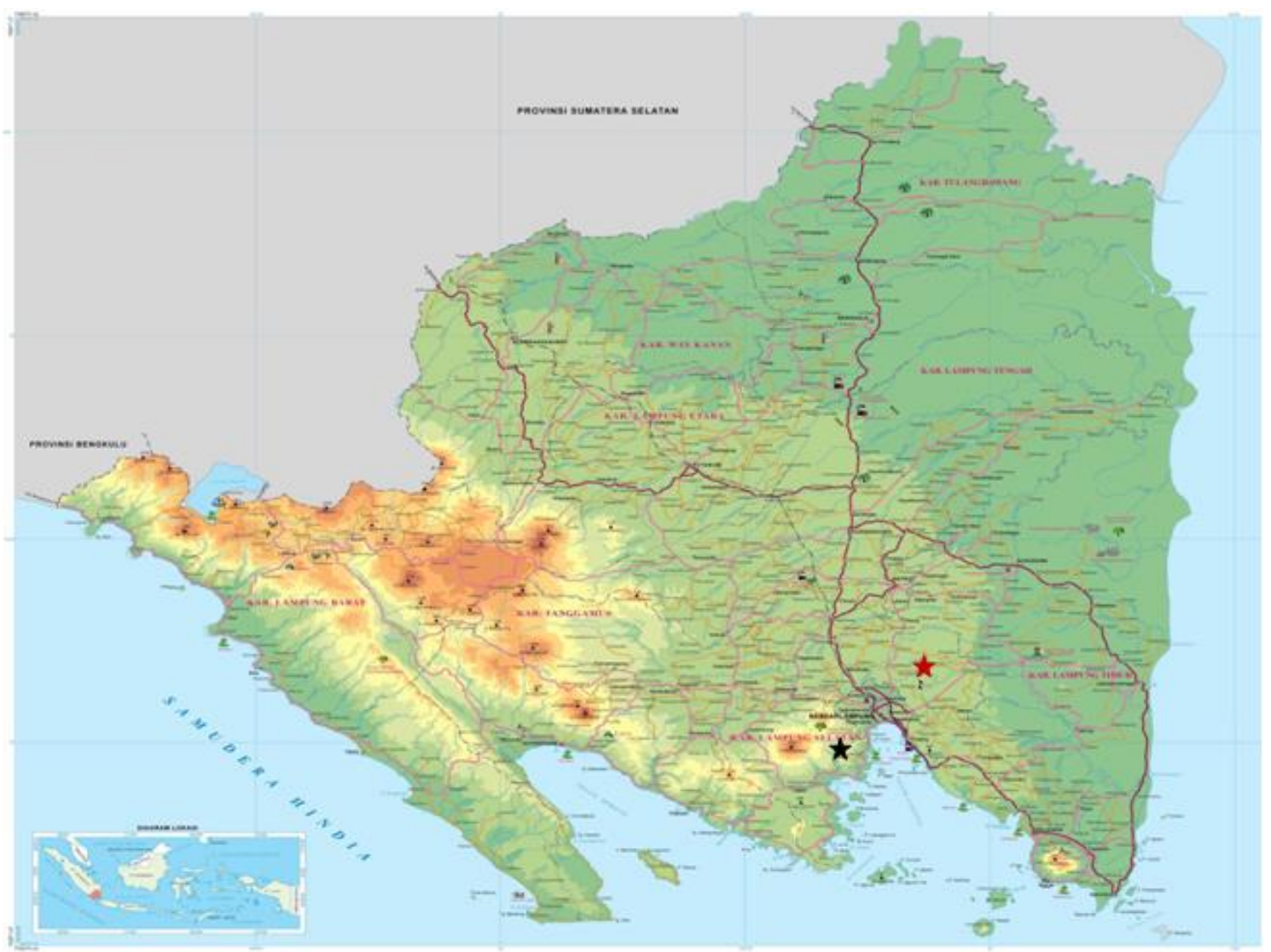

Figure 1. Research locations: Pesawaran Indah (black star) and Marga Lestari (red star).
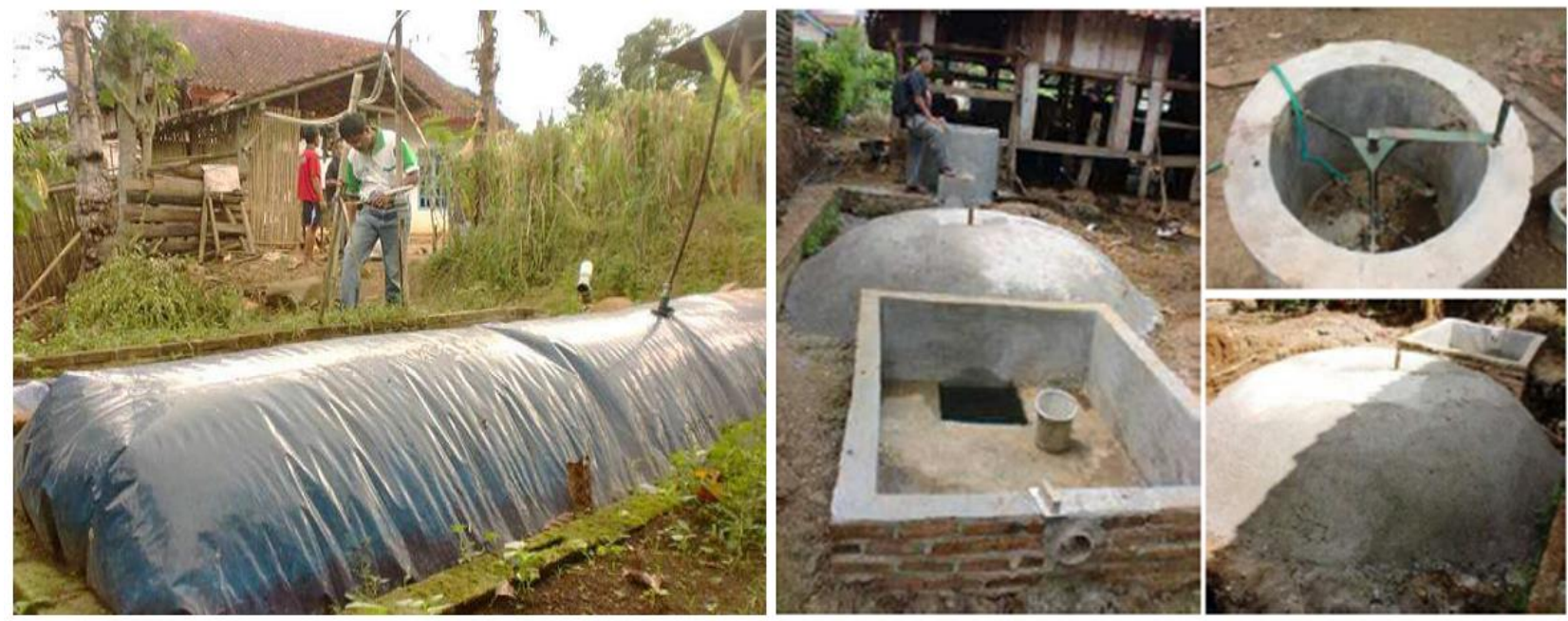

Figure 2. (a) Tubular plastic digester, and (b) fixed dome concrete digester.

Table 2.

Fresh cowdung and substrate characteristic (all parameters are presented in \% wet basis).

\begin{tabular}{|c|c|c|c|c|c|c|c|c|}
\hline \multirow{2}{*}{ Digester } & \multicolumn{2}{|c|}{ Water content } & \multicolumn{2}{|c|}{ Total solid } & \multicolumn{2}{|c|}{ Volatile solid } & \multicolumn{2}{|c|}{ Ash } \\
\hline & inlet & Outlet & Inlet & Outlet & inlet & outlet & inlet & Outlet \\
\hline A (plastic) & 92.23 & 94.17 & 7.77 & 5.83 & 5.66 & 3.80 & 2.11 & 2.03 \\
\hline B (plastic) & 91.70 & 94.92 & 8.30 & 5.08 & 5.27 & 2.23 & 3.03 & 2.85 \\
\hline C (dome) & 90.89 & 95.21 & 9.11 & 4.79 & 5.49 & 1.29 & 3.62 & 3.50 \\
\hline D (dome) & 91.61 & 95.06 & 8.39 & 4.94 & 6.28 & 2.88 & 2.12 & 2.03 \\
\hline Fresh dung & \multicolumn{2}{|c|}{77.82} & \multicolumn{2}{|c|}{22.19} & \multicolumn{2}{|c|}{16.72} & \multicolumn{2}{|c|}{5.47} \\
\hline
\end{tabular}


Citation: Haryanto, A., Cahyani, D., Triyono, S., Murdapa, F. and Haryono, D. (2017). Economic Benefit and Greenhouse Gas Emission Reduction Potential of A Family-Scale Cowdung Anaerobic Biogas Digester. Int. Journal of Renewable Energy Development, 6(1), 29-36, doi.org/10.14710/ijred.6.1.29-36

$\mathrm{P}$ a g e $\mid 32$

Table 2 showed characteristic of fresh cowdung used as substrate to operate the digesters. Substrate input is fresh cowdung mixed with water at a cowdungto-water ratio of $1: 1(\mathrm{v} / \mathrm{v})$. Substrate output is spent substrate or digestate flowing out of the digester outlet.

\subsection{Analysis and Measurements}

Proximate analysis was performed for fresh and spent substrate (cow dung) in order to determine water, total solid (TS), volatile solid (VS), and ash content. Water content was determined gravimetrically by drying sample in an oven at $105^{\circ} \mathrm{C}$ for 24 hours. Ash content of fresh and spent cowdung was analyzed by burning the material in a furnace (Barnstead Thermolyne 1300) at a temperature $500{ }^{\circ} \mathrm{C}$ for 2 hours. Chemical oxygen demand (COD) of fresh and spent substrate was analyzed using closed reflux method. Samples to be analysed for COD concentration include fresh cowdung taken from the pen, substrate input or fresh substrate (a mixture of cowdung and water just before loading into the digester), and spent substrate or digestate taken from the outlet of the digester. Hydraulic retention time (HRT) is calculated by dividing total load of each digester by loading rate.

The quantity of biogas production was estimated using pressure difference read at a simple U-tube water manometer equipped in the digester system. Biogas samples were collected using gas sampling bag. Biogas composition was analyzed using a gas chromatograph (Shimadzu GC2014) with TCD detector and Shincarbon column (4.0m length, 3mm inner diameter).

\subsection{Calculation}

The amount of methane emission was calculated by considering Methane Producing Potential (Bo) and methane conversion factor (MCF). The Bo is defined as the maximum amount of methane that can be produced from a given quantity of manure. IPCC (2006) suggested Bo value of $0.1 \mathrm{~m}^{3} \mathrm{CH}_{4} / \mathrm{kg}$ VS (volatile solid) of manure for non dairy cattle in developing countries. Methane conversion factor reflects the portion of Bo that is achieved. The MCF value varies with the climate (especially temperature) and the type of manure treatment. IPCC (2006) recommended MCF value of deep bedding of cattle dung for a long time ( $>1$ month) is $80 \%$ for warm climate (greater than $25^{\circ} \mathrm{C}$ ). Methane emission is estimated as the following:

$\mathrm{CH}_{4}=\mathrm{Bo} \times \mathrm{MCF} \times \mathrm{VS}$

Environmental benefit of digester was evaluated using total GHG emission reduction potential ( $\mathrm{GHG}_{\text {Tот }}$ ):

$\mathrm{GHG}_{\mathrm{TOT}}=\mathrm{GHG}_{\mathrm{CH} 4}+\mathrm{GHG}_{\mathrm{LPG}}+\mathrm{GHG}_{\mathrm{FERT}}$
Units for all terms in Equation 2 are represented in kilogram $\mathrm{CO}_{2}$ equivalent $\left(\mathrm{kg} \mathrm{CO}_{2} \mathrm{e}\right)$. $\mathrm{GHG}_{\mathrm{CH}}$ is calculated by multiplying the amount of methane estimated from pilled manure (Eq. 1) and the global warming potential of methane (GWP $\left.\mathrm{CH}_{4}\right)$ :

$\mathrm{GHG}_{\mathrm{CH} 4}=\mathrm{CH}_{4} \times \mathrm{GWP}_{\mathrm{CH} 4}$

$\mathrm{GHG}_{\mathrm{LPG}}$ is calculated by multiplying the amount of saved LPG (kg) due to biogas utilization for cooking and global warming potential of LPG burning:

$\mathrm{GHG}_{\mathrm{LPG}}=\mathrm{LPG} \times \mathrm{GWP} \mathrm{LPG}_{\mathrm{L}}$

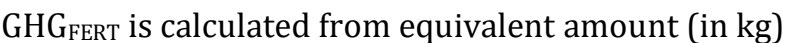
of $\mathrm{N}, \mathrm{P}$, and $\mathrm{K}$ fertilizer in the compost from spent slurry digestate and global warming potential of respected fertilizer production. In addition, global warming potential of nitrogen fertilizer application in form of $\mathrm{N}_{2} \mathrm{O}$ is also considered.

$$
\begin{aligned}
\mathrm{GHG}_{\mathrm{FERT}}= & \left(\mathrm{N} \times \mathrm{GWP}_{\mathrm{N}}\right)+\left(\mathrm{N} \times \mathrm{N}_{2} \mathrm{O}-\mathrm{N} \times \mathrm{GWP}_{\mathrm{N} 2 \mathrm{O}}\right) \\
& +(\mathrm{P} \times \mathrm{GWP})+\left(\mathrm{K} \times \mathrm{GWP}_{\mathrm{K}}\right)
\end{aligned}
$$

Table 3 lists global warming potential values for various sources used for calculating greenhouse gas emission reduction potential of a family-sized cowdung biogas digester.

Table 3.

\begin{tabular}{|c|c|c|c|}
\hline Parameter & Description & Value & References \\
\hline $\mathrm{GWP}_{\mathrm{CH} 4}$ & $\begin{array}{l}\text { Global warming potential } \\
\text { for methane burning } \\
\left(\mathrm{CO}_{2} \mathrm{e} / \mathrm{kg}\right)\end{array}$ & 21 & $\begin{array}{c}\text { Guinée } \\
\text { (2004) [23] }\end{array}$ \\
\hline $\mathrm{GWP}_{\mathrm{N}}$ & $\begin{array}{l}\text { Global warming potential } \\
\text { for nitrogen fertilizer } \\
\text { production }\left(\mathrm{CO}_{2} \mathrm{e} / \mathrm{kg}\right)\end{array}$ & 1.3 & $\begin{array}{l}\text { Pathak et al. } \\
\text { (2009) }\end{array}$ \\
\hline$G_{W P}$ & $\begin{array}{l}\text { Global warming potential } \\
\text { for phosphorous fertilizer } \\
\text { production }\left(\mathrm{CO}_{2} \mathrm{e} / \mathrm{kg}\right)\end{array}$ & 0.2 & $\begin{array}{l}\text { Pathak et al. } \\
\text { (2009) }\end{array}$ \\
\hline$G_{W} P_{K}$ & $\begin{array}{l}\text { Global warming potential } \\
\text { for potassium fertilizer } \\
\text { production }\left(\mathrm{CO}_{2} \mathrm{e} / \mathrm{kg}\right)\end{array}$ & 0.2 & $\begin{array}{l}\text { Pathak et al. } \\
\text { (2009) }\end{array}$ \\
\hline $\mathrm{N}_{2} \mathrm{O}-\mathrm{N}$ & $\begin{array}{l}\mathrm{N}_{2} \mathrm{O} \text { emission factor from } \mathrm{N} \\
\text { fertilizer application } \\
(\mathrm{kg} / \mathrm{kg})\end{array}$ & 0.07 & $\begin{array}{l}\text { Pathak et al. } \\
\text { (2009) }\end{array}$ \\
\hline $\mathrm{GWP}_{\mathrm{N} 20}$ & $\begin{array}{l}\text { Global warming potential } \\
\text { for } \mathrm{N}_{2} \mathrm{O}\left(\mathrm{CO}_{2} \mathrm{e} / \mathrm{kg}\right)\end{array}$ & 310 & $\begin{array}{l}\text { Guinée } \\
\text { (2004) }\end{array}$ \\
\hline $\mathrm{GWP}_{\mathrm{LPG}}$ & $\begin{array}{l}\text { Global warming potential } \\
\text { for LPG burning }\left(\mathrm{CO}_{2} \mathrm{e} / \mathrm{kg}\right)\end{array}$ & 3.00 & $\begin{array}{l}\text { Suhedi } \\
(2006)\end{array}$ \\
\hline
\end{tabular}

Global warming potential factors to calculate GHG emission reduction.

Economic benefit was estimated from LPG saving due to biogas utilization for cooking and slurry digestate utilization for replacing chemical fertilizers. 


\section{Results and Discussion}

Fresh cow manure has high potential to be used as a substrate in the process of digestion anaerobic because it contains high organic matter $(16.72 \%, \mathrm{w} / \mathrm{w})$. It is also evident from the high COD value, ranging from 82,553 to $104,038 \mathrm{mg} / \mathrm{L}$ with an average of $91,498 \mathrm{mg} / \mathrm{L}$. Fresh cow dung contains high total solid, TS (22.19\%, w/w), so it is not optimum for the anaerobic digestion process. In addition, with the water content of $77.82 \%(\mathrm{w} / \mathrm{w})$, the cowdung forms a paste-like substance which is difficult to flow. These conditions are not ideal for wet anaerobic digestion process that requires a TS maximum level of $9 \%$ (Yavini et al., 2014) to ensure an optimum process. Therefore, in practice the cow dung should be diluted with water at a ratio of cow dung to water of about 1: $1(\mathrm{v} / \mathrm{v})$. By using the dilution, substrate contains $8.39 \%$ of TS and ready to be loaded into the process of anaerobic digestion.

Comparing influent and effluent characteristic as in Table 2, it is revealed that TS, VS, and ash content of the substrate decreased, while water content increased during biogas process. During anaerobic digestion process, a portion of VS is converted into stable gases such as $\mathrm{CO}_{2}$ and $\mathrm{CH}_{4}$. Therefore, VS and TS decreased during biogas process. Another explanation is that for digesters with no stirring mechanism there is a problem related to settling process. Solid settling causes the effluent become more dilute so that TS and VS contents decrease while water content increases. This process also explains why ash content decreases even though ash is considered as inert material.

Methane forming reaction from $\mathrm{CO}_{2}$ and $\mathrm{H}_{2}$ route also produces $\mathrm{H}_{2} \mathrm{O}$ :

$\mathrm{CO}_{2}+4 \mathrm{H}_{2} \rightarrow \mathrm{CH}_{4}+\mathrm{H}_{2} \mathrm{O}$

The water, however, is usually carried in the biogas and should not increase water content of the effluent.

\subsection{Digester performance}

Table 4 presented operating condition of digesters. Anaerobic digesters in this research work were in conditions close to normal with an average $\mathrm{pH}$ of 7.83 to 8.32. This is a good condition for the process of anaerobic digestion. Yadvika et al. (2004) reported the optimal $\mathrm{pH}$ for anaerobic digestion process is as narrow as the range between 6.8 and 7.2. Other research reported the range between 5.5 and 8.5 (RISE-AT, 1998). Anaerobic digestion process destroys organic matter (volatile solid) to produce biogas and a more stable material (digestate). With an average hydraulic retention time (HRT) of 35 days, digesters capable to decompose organic material and decrease the COD value from 45,749 to $22,476 \mathrm{mg} / \mathrm{L}$. Thus, the COD removal reached an average of $51.32 \%$. COD removal can be improved by increasing the HRT (size of the digester). It is not easy to be executed, however, because of the limited space.
Theoretically, every kg of COD removal may produce $\mathrm{CH}_{4}$ as much as $0.350 \mathrm{Nm}^{3}$ (Manariotis et al., 2010) or $0.388 \mathrm{~m}^{3}$ at a temperature of $30^{\circ} \mathrm{C}$. Digesters evaluated in this research produced average $247.6 \mathrm{~L} \mathrm{CH}_{4} / \mathrm{kg} \mathrm{COD}$ removal (Table 5). Based on this value, the digesters have a fairly good efficiency, reaching $63.8 \%$.

Digesters were capable of producing daily biogas at rate of $1582 \mathrm{~L} /$ unit/day or $280.3 \mathrm{~L} /$ head of cow (Table $5)$. Average methane content of the biogas was $53.61 \%$ (Table 6), meaning that energy value produced from a family-scale digester was $1121.2 \mathrm{MJ}$ /day or 7858.6 $\mathrm{MJ} /$ year. By taking low heating value (LHV) for LPG as much as $46.6 \mathrm{MJ} / \mathrm{kg}$ (Wright et al., 2009), the biogas is equivalent to $169 \mathrm{~kg}$ of LPG/year. For the purposes of domestic cooking, Indonesia has marketed $3 \mathrm{~kg}$ so that the biogas can replace 56 bottles of LPG per year. Our observation, however, showed that every unit of digester was capable of replacing one bottle LPG need per week or 52 bottles/year.

Table 4.

Digester operating condition.

\begin{tabular}{lccccc}
\hline \multirow{2}{*}{ Parameter* } & \multicolumn{5}{c}{ Digester } \\
\cline { 2 - 6 } & $\begin{array}{c}\text { A } \\
\text { plastic }\end{array}$ & $\begin{array}{c}\text { B } \\
\text { plastic }\end{array}$ & C dome & $\begin{array}{c}\text { D } \\
\text { dome }\end{array}$ & Average \\
\hline pH in & 8.41 & 8.15 & 8.34 & 8.37 & 8.32 \\
pH out & 7.80 & 7.83 & 7.83 & 7.86 & 7.83 \\
$\begin{array}{l}\text { Number of } \\
\text { cow (head) }\end{array}$ & 3 & 4 & 6 & 5 & 5 \\
$\begin{array}{l}\text { Loading rate } \\
\text { (L/head/day) }\end{array}$ & 26.7 & 20.0 & 25.0 & 24.0 & 22.67 \\
$\begin{array}{l}\text { Total load } \\
\text { (L/head) }\end{array}$ & 715.7 & 883.6 & 750.0 & 900.0 & 812.3 \\
HRT (day) & 27 & 44 & 30 & 38 & 35 \\
COD in (mg/L) & 46,964 & 41,276 & 42,736 & 52,019 & 45.749 \\
COD out (mg/L) & 23,360 & 19,112 & 17,941 & 29,492 & 22,476 \\
$\begin{array}{l}\text { CDD removal } \\
\text { (COD })(m g / L)\end{array}$ & 23,604 & 22,164 & 24,795 & 22,527 & 23,373 \\
$\begin{array}{l}\text { CDD removal } \\
\text { (COD } \text { ) (\%) }\end{array}$ & 50.26 & 53.70 & 58.02 & 43.31 & 51.32 \\
\hline & & & & & \\
\hline
\end{tabular}

Table 5.

Biogas and methane yield and digester efficiency.

\begin{tabular}{|c|c|c|c|c|c|c|}
\hline \multirow{2}{*}{ Digester } & \multirow{2}{*}{$\begin{array}{l}\text { No. of } \\
\text { cow } \\
\text { (head) }\end{array}$} & \multicolumn{3}{|c|}{ Biogas yield } & \multirow{2}{*}{$\begin{array}{c}\mathrm{CH}_{4} \text { yield } \\
\mathrm{L} / \mathrm{kg} \\
\mathrm{COD}_{\mathrm{r}}\end{array}$} & \multirow{2}{*}{$\begin{array}{c}\text { Digester } \\
\text { efficiency } \\
(\%)\end{array}$} \\
\hline & & $L / d$ & L/head/d & $\mathrm{L} / \mathrm{kg} \operatorname{COD}_{\mathrm{r}}$ & & \\
\hline C dome & 6 & 2164 & 360.7 & 581.8 & 315.0 & 81.2 \\
\hline D dome & 5 & 1000 & 200.0 & 369.9 & 180.2 & 46.4 \\
\hline Average & & 1582 & 280.3 & 475.9 & 247.6 & 63.8 \\
\hline
\end{tabular}

\subsection{GHG potential reduction}

Total GHG emission potential was composed of biomethane potential of cowdung management (pilling up), GHG emission from LPG saving, and GHG emission from fertilizer saving. Pilling up the manure will result 
Citation: Haryanto, A., Cahyani, D., Triyono, S., Murdapa, F. and Haryono, D. (2017). Economic Benefit and Greenhouse Gas Emission Reduction Potential of A Family-Scale Cowdung Anaerobic Biogas Digester. Int. Journal of Renewable Energy Development, 6(1), 29-36, doi.org/10.14710/ijred.6.1.29-36

$\mathrm{P}$ a g e $\mid 34$

in an anaerobic process that emits methane to the atmosphere.

Table 6.

Biogas composition $(\%, v / v)$.

\begin{tabular}{lccccc}
\hline \multirow{2}{*}{ Parameter } & \multicolumn{5}{c}{ Digester } \\
\cline { 2 - 6 } & $\begin{array}{c}\text { A } \\
\text { plastic }\end{array}$ & $\begin{array}{c}\text { B } \\
\text { plastic }\end{array}$ & $\begin{array}{c}\text { C } \\
\text { dome }\end{array}$ & $\begin{array}{c}\text { D } \\
\text { dome }\end{array}$ & Average \\
\hline Methane $\left(\mathrm{CH}_{4}\right)$ & 53.87 & 57.70 & 54.14 & 48.71 & 53.61 \\
Carbon dioxide & 25.79 & 31.99 & 34.90 & 32.72 & 31.35 \\
$\left(\mathrm{CO}_{2}\right)$ & 20.34 & 10.30 & 10.95 & 18.56 & 15.04 \\
Nitrogen $\left(\mathrm{N}_{2}\right)$ & & & & & \\
\hline
\end{tabular}

With an average cow weight of $300 \mathrm{~kg} / \mathrm{head}$ and using manure production $5.8 \%$ of living weight (ASAE, 2003), then every head of cow produces annual fresh dung of $6351 \mathrm{~kg}$ with VS content of $16.72 \%$ (Table 2). According to Equation (1), annual $\mathrm{CH}_{4}$ emission potential is calculated to be $42.5 \mathrm{~m}^{3} /$ head. However, farmers usually let the cow to graze during the day, and the droppings are splattered over the field so that the potential of cow dung was one half of it (during night only). Thus, the annual GHG emission potential from piled cow manure reaches $21.24 \mathrm{~m}^{3} /$ head, equivalent to $308.6 \mathrm{~kg} \mathrm{CO}_{2} \mathrm{e}$ per head or $1592.8 \mathrm{~kg} \mathrm{CO}_{2} \mathrm{e}$ for every digester with 5 cows. This emission can be reduced by introducing manure into the digester and capturing the biogas for cooking fuel, replacing LPG.

As listed in Table 3, global warming potential for LPG burning is $3.00 \mathrm{~kg} \mathrm{CO} 2 \mathrm{e} / \mathrm{kg}$. With LPG saving of 52 bottles per year, it follows that equivalent of $\mathrm{GHG}$ reduction due to LPG substitution by biogas was $468 \mathrm{~kg}$ $\mathrm{CO}_{2} \mathrm{e} /$ year.

Fertilizer potential of slurry digestate (effluent) is represented by the amount of digestate as well as $\mathrm{N}, \mathrm{P}$, and $\mathrm{K}$ con-tent. In this case, the amount of digestate is assumed to be equal to the substrate loading rate. Because of high water content in the digestate, it is assumed that density of digestate is same as that for water $(1 \mathrm{~kg} / \mathrm{L})$. The amount of slurry digestate was 22.7 $\mathrm{kg} /$ day per head of cow which was equivalent to dry matter of $2134.8 \mathrm{~kg} /$ year for a digester with 5 heads of cow. The content of $\mathrm{N}, \mathrm{P}, \mathrm{K}$ in the digestate was $1.24 \%$, $0.19 \%$, and $1.05 \%(\mathrm{w} / \mathrm{w}$, dry basis), respectively. This meant the digestate was corresponding to $57.55 \mathrm{~kg}$ UREA (N fertilizer, 46\%), $11.27 \mathrm{~kg}$ SP36 (P fertilizer, $36 \%$ ), and $37.36 \mathrm{~kg} \mathrm{KCl} \mathrm{(K} \mathrm{fertilizer,} \mathrm{60 \% ).} \mathrm{Application}$ of slurry digestate as compost reduced GHG emission by $614 \mathrm{~kg} \mathrm{CO} 2 \mathrm{e} /$ year. Based on our calculations, family biogas digester with 5 heads of cow potentially reduced GHG emissions by $2674.8 \mathrm{~kg} \mathrm{CO} 2 \mathrm{e} /$ year (Table 7). This value is lower than the study in India by Pathak et al. (2009). This can be resulted from a fact that digester in our study used cow dung collected during night time only.
Table 7.

Annual GHG potential reduction of a family-sized biogas digester

\begin{tabular}{|c|c|}
\hline Parameter & Value $\left(\mathrm{kg} \mathrm{CO}_{2} \mathrm{e}\right)$ \\
\hline $\begin{array}{l}\text { GHG emission from biomethane potential } \\
\text { resulted from manure management }\end{array}$ & 1592.8 \\
\hline GHG emission from LPG saving & 468.0 \\
\hline GHG emission from fertilizer saving & 614.0 \\
\hline Total GHG emission reduction potential & 2674.8 \\
\hline
\end{tabular}

\subsection{Economic Benefit}

Economic benefit of a biogas digester was calculated based on LPG saving by biogas and fertilizer saving by slurry digestate. Biogas cost was assumed to be zero because all works related to digester operation and maintenance were conducted by a family members with no pay. In addition, all digesters evaluated in this study were developed by donors for free. Therefore, no interest and depreciation were made to evaluate economic benefit.

Recently, a bottle LPG @ 3 kg was marketed at a price of 20,000 IDR or 1.54 USD at a currency rate of 13,000 IDR/USD. Our observation found that a bottle of LPG @ $3 \mathrm{~kg}$ is enough to meet a week of regular cooking. Therefore, every family spent about 1,040,000 IDR/year (USD 80.0 USD/year) for LPG. If the family operate a digester, LPG consumption is completely substituted by biogas. Economic benefit from biogas utilization is $1,040,000 \mathrm{IDR} /$ year or $80 \mathrm{USD} /$ year.

The price of UREA is $2850 \mathrm{IDR} / \mathrm{kg}, \mathrm{SP} 36$ is 3350 IDR/ $\mathrm{kg}$ and $\mathrm{KCl}$ is $5600 \mathrm{IDR} / \mathrm{kg}$. This meant that slurry digestate produced from a biogas digester potentially contribute to economic benefits from fertilizer saving by $410,970 \mathrm{IDR} /$ year or $31.61 \mathrm{USD} /$ year at a currency of $13,000 \mathrm{IDR} / \mathrm{USD}$.

The total economic benefit of biogas digester was $1,450,970$ IDR/year or 111.6 USD/year. This was not a great value, however, so it can be understood if people were not eager in operating biogas digester. When compared to the cost of installation, which reached 2,000,000 IDR/unit (153.85 USD/unit) for plastic digester (Haryanto and Triyono, 2011) and 6,500,000 IDR/unit (500 USD/unit) for $6 \mathrm{~m}^{3}$ concrete fixed-dome digester (Hariyanto, 2012), obviously that biogas construction was not impressing to villagers. This explains why dissemination of family-sized biogas digesters are developing slowly.

\subsection{Future Prospect of Biogas in Lampung}

Biogas digester has triple advantages: producing fuel, producing organic fertilizer, and reducing greenhouse gas emissions. Therefore, the household scale biogas digester has good prospects to be developed in Lampung. In addition, we also observed that farmers raising cattle of three or more heads can be found easily. Three is the minimum number of cow to operate a family size digester with biogas production sufficient for cooking. 
Nevertheless, we also observed that more than $50 \%$ of biogas digester that has been installed from a variety donors was collapsed within 1 to 3 years of installation. Plastic digesters, though less expensive, are generally more breakable than concrete digesters. One way to solve this problem is developing biogas digester with multi purposes, and is not merely to produce biogas fuel. Slurry digestate is an important link between biogas and agriculture (Vorley et al., 2015). Therefore, biogas installation must be accompanied by organic fertilizer production and smallholder agriculture.

\section{Conclusion}

A family size anaerobic cowdung biogas digester with 5 heads of cow potentially reduced greenhouse gas emission by $2674.8 \mathrm{~kg} \quad \mathrm{CO}_{2}$ equivalent per year compiled of $1592.8 \mathrm{~kg}$ from $\mathrm{CH}_{4}$ saving due to manure management, $468 \mathrm{~kg}$ from LPG saving, and $614 \mathrm{~kg}$ from fertilizer saving. In addition, the biogas utilization also provided annual economic benefit of 1,450,970 IDR/year 111.6 USD/year. Development biogas digester has to be integrated with organic fertilizer production and smallholder agriculture.

\section{Acknowledgments}

Part of this research was supported by DP2M DIKTI through RUSTRANAS with a contract number of 599/UN26.8/PL/2013 (September 2, 2013). The views expressed in this paper, however, are solely of the authors.

\section{References}

An, B.X., Preston, T.R., \& Dolberg, F. (1997) The introduction of lowcost polyethylene tube biodigesters on small scale farms in vietnam. Livestock Research for Rural Development, 11(1). http://www.lrrd.org/lrrd9/2/an92.htm (Accessed July 10, 2015).

ASAE (American Society of Agricultural Engineers). (2003) Manure production and characteristics (ASAE D384.1 FEB03).

Barnhart, S. (2014) From household decisions to global networks: biogas and the allure of carbon trading in Nepal. The Professional Geographer, 66(3): 345-353.

Bird, L. \& Sumner, J. (2014) Using renewable energy purchases to achieve institutional carbon goals: A review of current practices and considerations. NREL Report No. TP-6A20-49938. http://www.nrel.gov/docs/fy11osti/49938.pdf (April 14, 2014)

BPS Lampung. (2013) Lampung in figures. Statistical Bureau of Lampung: 217

Chen, Y., Hua, W., Feng, Y., \& Sweeney, S. (2014) Status and prospects of rural biogas development in China. Renewable and Sustainable Energy Reviews, 39: 679-685.

Feng, Y., Guo, Y., Yang, Y., Qin, X., \& Song, Z. (2014) Household biogas development in rural China: On policy support and other macro sustainable conditions. Renewable and Sustainable Energy Reviews, 16: 679-685.

Forte, A.J. (2011) A Glimpse into community and institutional biogas plants in Nepal. http://my.ewbusa.org/theme/library/myewb-usa/projectresources/technical/2-1440-a-glimpse-into-community-andinstitutional-biogas-plants-in-nepal.pdf (Accessed July 7, 2015)

Ghimire, P.C. (2013) SNV supported domestic biogas programmes in Asia and Africa. Renewable Energy, 49: 90-94.
Guinée, J.B. (2004) Handbook on life cycle assessment: Operational guide to the ISO standards. New York. Kluwer Academic Publishers: 185.

Hariyanto. (2012) Model pengembangan energi alternatif biogas di KPSP Setia Kawan (Biogas alternative energy development model at KPSP Setia Kawan). Presentation at Workshop Coordination Biogas Rumah (BIRU) Program, Lampung, Oktober 23, 2012.

Haryanto, A. \& Triyono, S. (2011) Kinerja biogas skala rumah tangga. Prosiding Seminar BKS PTN Barat. (Performance of family size biogas digester. In Proceeding of BKS PTN Barat Seminar). Editors: Abrar A, Muslim G, Rosana E, Thirtawati, Oktarina S, Agustina H, Aryani D. Sriwijaya University, Palembang: 860866.

IPCC (The Intergovernmental Panel on Climate Change). (2006) 2006 IPCC guidelines for national greenhouse gas inventories Volume 4: Agriculture, forestry and other land use. Institute for Global Environmental Strategies (IGES), Hayama, Japan: 10.110.87

Kabir, H., Palash, M.S., \& Bauer, S. (2012) Appraisal of domestic biogas plants in Bangladesh. Bangladesh Journal of Agricultural Economics, XXXV(1\&2): 71-89.

Kabir, H., Yegbemey, R.N., \& Bauer, S. (2013) Factors determinant of biogas adoption in Bangladesh. Renewable and Sustainable Energy Reviews, 28: 881-889.

Kandpal, T.C., Bharati, J., \& Sinha, C.S. (1991) Economics of family sized biogas plants in India. Energy Conversion \& Management, 32: 101-113.

Khan, U.K., Mainali, B., Martin, A., \& Silveira, S. (2014) Technoeconomic analysis of small scale biogas based polygeneration systems: Bangladesh case study. Sustainable Energy Technologies and Assessments, 7: 68-78.

Lie, A. (2009) Program konversi minyak tanah ke elpiji: Potret kebijakan pemerintah dalam sektor pengelolaan energi nasional (Kerosene-to-LPG conversion program: A portrait of government policy in national energy management sector). Stadium General, Diponegoro University, Semarang. January 10, 2009.

Manariotis, I.D., Grigoropoulos, S.G., \& Hung, Y-T. (2010) Anaerobic treatment of low-strength wastewater by a biofilm reactor. In Environmental Bioengineering. Eds. Wang, L.K., Tay, J-H., Tay, ST-L., \& Hung, Y-T. Humana Press, New York: 445-496

Nguyen, V.C.N. (2011) Small-scale anaerobic digesters in Vietnam Development and challenges. Journal of Vietnamese Environment, 1(1): 12-18.

Pathak, H., Jain, N., Bhatia, A., Mohanty, S., \& Gupta, N. (2009) Global warming mitigation potential of biogas plants in India. Environment Monitoring Assessment, 157: 407-418

RISE-AT (Regional Information Service Centre for South East Asia on Appropriate Technology). (1998) Review of current status of anaerobic digestion technology for treatment of municipal solid http://www.ist.cmu.ac.th/riseat/documents/adreview.pdf (Accessed July 10, 2015)

Singh, K.J. \& Sooch, S.S. (2004) Comparative study of economics of different models of family size biogas plants for state of Punjab, India. Energy Conversion \& Management, 45: 13291341.

Schmidt, T. S. \& Dabur, S. (2014) Explaining the diffusion of biogas in India: a new functional approach considering national borders and technology transfer. Environmental Economics and Policy Studies, 16, 171-199.

Suhedi, F. (2006) Keterkaitan aktivitas domestik dengan emisi $\mathrm{CO}_{2}$ (Relationship between domestic activities to $\mathrm{CO}_{2}$ emission). Presentation at Workshop "Alternatif Rancangan Permukiman Perkotaan Berdasarkan Emisi $\mathrm{CO}_{2}$ " (Urban Planning Alternative Based on $\mathrm{CO}_{2}$ Emission). Bandung, March 21, 2006. In Bahasa Indonesia.

Vorley, B., Porras, I., \& Amrein, A. (2015) The Indonesia Domestic Biogas Programme: can carbon financing promote sustainable agriculture? IIED (International Institute for Environment and Development) and Hivos. 80-86 Gray's Inn Road, London WC1X 8NH, UK: 10. 
Citation: Haryanto, A., Cahyani, D., Triyono, S., Murdapa, F. and Haryono, D. (2017). Economic Benefit and Greenhouse Gas Emission Reduction Potential of A Family-Scale Cowdung Anaerobic Biogas Digester. Int. Journal of Renewable Energy Development, 6(1), 29-36, doi.org/10.14710/ijred.6.1.29-36

$\mathrm{P}$ a g e $\mid 36$

Wright, L., Boundy, B., Badger, P.C., Perlack, B., \& Davis, S. (2009) Biomass Energy Data Book. 2nd edition. Oak Ridge National Laboratory, Oak Ridge, Tennessee: 189.

Yadvika, S., Sreekrishnan, T.R., Kohil, S., \& Rana, V. (2004) Enhancement of biogas production from solid substrates using different techniques: A review. Bioresource Technology, 95: 1-10.

Yavini, T.D., Chia, A.I., \& John, A. (2014) Evaluation of the effect of total solids concentration on biogas yields of agricultural wastes. International Research Journal of Environment Sciences, 3(2): 70-75. 